Editorial

\title{
German Virtues in an International Journal
}

\author{
Andreas Böning ${ }^{1}$ Bernd Niemann ${ }^{1}$ \\ ${ }^{1}$ Klinik für Herz-, Kinderherz- und Gefäßchirurgie, Standort Gießen, \\ Universitätsklinikum Gießen und Marburg GmbH, Gießen, Germany \\ Thorac Cardiovasc Surg Rep 2018;7:e46.
}

With this editorial, we would like to announce the change in editorship for The Thoracic and Cardiovascular Surgeon Reports (TCSR). Having served as an editor since its inception in 2012, Andreas Böning has decided to step back because he has assumed new obligations in his university hospital. The gap is filled by Bernd Niemann who was elected by the board of directors of the German Society for Thoracic and Cardiovascular Surgery (GSTVS/DGTHG) in agreement with Thieme Publishers and the Editor-in-Chief of the mother journal The Thoracic and Cardiovascular Surgeon.

If you look at it from a nautical side, Captain Böning has been followed by his clinical first officer Niemann, which promises a certain amount of continuity. The once taken course of TCSR will go on steadily. TCSR is still an international journal of a German society, published by Thieme in Stuttgart, which guarantees several German virtues:

- Geschwindigkeit, nicht Gemütlichkeit (speed, not coziness): The mean time until a final decision is reached for a manuscript is 30 days, comparably short for a peerreviewed journal.

- Gründlichkeit (thoroughness): A thorough review process is one of the prerequisites Thieme has written on its flags. We do not publish papers only because authors pay for them, but we also check all manuscripts for content, including potential fraud or plagiarism.

- Ehrlichkeit, nicht Eiligkeit (honesty, not urgency): Without a peer-review process, the publication time would be faster, but-as said above-the thoroughness would not be the same.
We all know that open-access (OA) journals abound. We personally receive emails with invitations for publication or editorial boards every day. Not all OA journals are dedicated to scientific accuracy by peer reviewing and by rejecting papers not fitting high standards, like the TCSR is.

The further course of TCSR will lead us eventually to the shores of "impact factor county," having passed the cliffs of the "Emerging Sources" already. Although surgeons like to read case reports and hopefully can learn from them, the "impact factor" of case report journals is usually low. However, evidence-based medicine does not only stop with randomized trials guidelines and meta-analyses but also counts on the expertise of therapists and on patients' demands. The expertise of therapists is often published as a description of special cases: for example, minimal-invasive mitral valve repair was introduced by a single institution's case series and widely adopted thereafter without confirmation of advantages and disadvantages in a randomized trial.

Lastly, the fare to the shores of "impact factor county" has to be paid, which brings us to the subject of $\mathrm{OA}$ article processing charges. Although we could have earned more money with the journal, our acceptance rate is only $60 \%$. This shows that our focus is on publishing sound case reports and rejecting unreadable manuscripts, manuscripts containing the umpteenth repetition of a certain problem, or plagiarism. TCSR offers high-quality case reports to read "for free" to a broad community of aspiring juniors and seniors wistful for knowledge.

Let's keep our TCSR ship on this steady course!
Address for correspondence Andreas Böning, MD, Klinik für Herz-, Kinderherz- und Gefäßchirurgie, Standort Gießen, Universitätsklinikum Gießen und Marburg GmbH, Rudolf-

Buchheim-Street 7, 35392

Gießen, Germany

(e-mail: Andreas.Boening@chiru. med.uni-giessen.de).
DOI https://doi.org/ 10.1055/s-0038-1675402. ISSN 2194-7635. (C) 2018 Georg Thieme Verlag KG
Stuttgart · New York
License terms

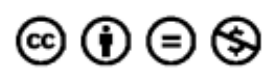

